\title{
Orðaforðakennsla með sögulestri fyrir börn með málproskaröskun
}

\author{
Sigrún Alda Sigfúsdóttir, Jóhanna T. Einarsdóttir, \\ Dorlákur Karlsson og Íris Ösp Bergpórsdóttir \\ Abstract Um höfundana About the authors \\ - Heimildir
}

Tilgangur rannsóknarinnar var að bera saman áhrif beinnar og óbeinnar orðaforðakennslu hjá börnum með málproskaröskun. Einkenni málproskaröskunar er slök færni í tungumálinu, bæði í málskilningi og máltjáningu. Beina orðaforðakennslan fólst í að lesa sögubók og skoða hvort börn lærðu ný orð með pví að útskýra og vinna sérstaklega með ákveðin markorð sem komu fyrir í textanum. Við óbeina kennslu var sama bók lesin án pess að staldra við markorðin eða útskýra pau. Dátttakendur voru tveir, báđir í elsta árgangi í leikskóla, og höfðu niðurstöður málproskamælinga fyrir íhlutun sýnt slaka færni, bæði í málskilningi og máltjáningu. Kennslan fór fram í leikskóla barnanna fjórum sinnum í viku, í sex vikur. Niðurstöður leiddu í ljós að góður árangur náðist með pann orðaforða sem kenndur var með beinni kennslu. Orðaforði barnanna jókst hins vegar mun minna við óbeina kennslu. Sú pekking sem börnin höfðu tileinkað sér að lokinni íhlutun hélst að nokkru leyti mánuði eftir að íhlutun lauk. Mikilvægt er að lesa fyrir leikskólabörn og skapa aðstæður par sem markvisst er verið að kenna ný orð. Jafnframt er nauðsynlegt að huga sérstaklega vel að börnum með slaka málfærni og auðvelda peim að hlusta á sögu með pví að útskýra orð jafnóðum. Pessar niðurstöður gefa vísbendingar um að til að auka orðaforða barna við sögulestur purfi að útskýra ný orð sérstaklega. Foreldrar, kennarar og talmeinafræðingar geta ekki gert ráð fyrir að börn tileinki sér ný orð með pví að heyra pau lesin í sögubók og geti sér til um pýðingu peirra út frá samhengi.

Efnisord: Bein og óbein orðaforðakennsla, málproski, málproskaröskun, lestur sögubóka

\section{Inngangur}

Málfærni leikskólabarna er mjög breytileg, sum börn eru leikin við að orða hugsun sína og pekkja mikinn fjölda orða en önnur pekkja færri orð og eiga erfiðara með að orða pað sem pau eru að hugsa. Talið er að 9\% nemenda séu með málproskaröskun (e. Developmental Language Disorder, DLD) (Law, 2019). Málproskaröskun getur haft víðtæk áhrif bæði á nám og samskipti (Paul, Norbury og Gosse, 2018) en rannsóknir hafa sýnt að málfæri barna við fimm ára aldur spáir fyrir um árangur peirra í námi síðar meir (Catts, Fey, Tomblin og Zhang, 2002; Jóhanna T. Einarsdóttir, Amalía Björnsdóttir og Ingibjörg Símonardóttir, 2016). Dess vegna er brýnt að veita börnum sem greinast með málproskaröskun viðeigandi aðstoð eins fljótt og hægt er og efla málproska peirra leikskólabarna sem standa höllum fæti. Að lesa sögur fyrir börn hefur verið talin góð leið til að auka orðaforða og efla málfærni peirra (Paul o.fl., 2018). Markviss orðaforðakennsla með lestri sögubóka (e. storybook reading) hefur talsvert verið rannsökuð erlendis en lítið hér á landi. Aðferðin byggist á að við lestur sögubóka eru valin ákveðin orð (hér eftir kölluð markorð) sem börnin eru líkleg til að eiga erfitt með að skilja og pau orð útskýrð sérstaklega. Í pessari 
rannsókn verður athugað hvort hægt sé að auka orðaforða barna með málproskaröskun með pví að lesa sögubók og beita markvissri orðaforðakennslu. Orðanám barnanna var kannað, annars vegar með pví að lesa sögu og útskýra og vinna sérstaklega með markorðin samkvæmt aðferð beinnar kennslu (e. explicit instruction), og hins vegar án pess að útskýra markorðin sérstaklega, eða með óbeinni kennslu (e. implicit instruction).

\section{Hvað er málproskaröskun?}

Barn sem sýnir marktækt slakari færni í málbroska en jafnaldrar gæti verið með málproskaröskun. Við greiningu er stuðst við niðurstöður mælinga á formlegum málproskaprófum en einnig við óformlegar athuganir og mat sérfræðinga (Law, 2019). Málproskapróf athuga bæði skilning og tjáningu tungumálsins og er peim skipt niður í pætti sem varða innihald, form og notkun pess. Merkingarfræði (e. semantics) tekur til innihalds tungumálsins, hljóðkerfisfræði (e. phonology), setningafræði (e. syntax) og orðhlutafræði (e. morphemics) snúa að formi pess og að lokum nær málnotkun (e. pragmatics) yfir notkun málsins (Paul o.fl., 2018). Barn með málproskaröskun á oft í erfiðleikum með alla pætti tungumálsins pótt töluverður einstaklingsmunur og breytileiki sé innan hópsins. Birtingarmynd röskunarinnar lýsir sér í að barnið beitir ekki málfræðireglum rétt, pað einfaldar setningar og orðaforðinn er einsleitur. Málnotkun barna með málproskaröskun birtist í erfiðleikum með að halda sér við umræðuefni, að skiptast á að tala, að segja frá á skipulegan hátt og fylgja almennum reglum sem einstaklingar tileinka sér í samskiptum. Tvítyngt eða fjöltyngt barn getur einnig verið með málbroskaröskun og kemur hún pá fram í öllum tungumálum sem pað tileinkar sér.

Málproskaröskun hefur verið kölluð ýmsum nöfnum, eins og seinn málproski (e. language delay), málhömlun (e. language impairment) eða sértæk málproskaröskun (e. specific language disorder). Árið 2016 vann alpjóðlegur hópur, svokallaður CATALISE-hópur, að pví að sammælast um viðmið fyrir frávik í málproska. Dátttakendur voru 57 sérfræðingar úr tíu ólíkum starfsstéttum, svo sem talmeinafræðingar, sálfræðingar, kennarar, læknar og einnig fulltrúar úr fjölskyldum barna sem voru með frávik í málproska. Hópurinn ákvað að nota hugtakið málproskaröskun (e. DLD) ef frávik í málproska væru vegna ópekktra orsaka. Hópurinn lagði jafnframt til að hugtakið málröskun (e. language disorder) yrði notað yfir frávik í máli sem fylgdu pekktri fötlun og pá væri fjallað um málröskun tengda einhverfu eða málröskun tengda Downs-heilkenni (Bishop, Snowling, Thompson og Greenhalgh, 2016, 2017). Ákvarðanir hópsins hafa haft víðtæk áhrif á alpjóðlega umfjöllun vísindamanna og greiningu á málbroskafrávikum barna og unglinga. Greiningarviðmið voru einfölduð pannig að ef barn greinist á eftir í máli prátt fyrir að hafa fengið viðhlítandi málörvun úr umhverfinu er talið að bað sé með málproskaröskun. Ekki purfa að liggja fyrir proskamælingar með greindarprófum eins og áður var skilyrði pegar um var að ræða sértæka málproskaröskun. Alpjóðlegir hópar hafa jafnframt unnið að pví að auka pekkingu og vitund um málproskaröskun, meðal annars undir merkjum RADLD - Raising Awareness of Developmental Language Disorders (RADLD, e.d.).

Orðaforði barna með málproskaröskun

Eitt megineinkenni málproskaröskunar er slakur orðaforði. Orðaforði (e. vocabulary) er skilgreindur sem sá fjöldi orða sem einstaklingur hefur á valdi sínu (Hiebert og Kamil, 2005). Вæði er átt við hversu mörg orð einstaklingurinn pekkir, p.e. stærð orðaforðans, og hversu vel hann skilur hvert orð, eða dýpt orðaforðans (McGregor, Oleson, Bahnsen og Duff, 2013).

Börn með málproskaröskun eru oft sein til að segja fyrsta orðið og pau eru lengur að læra ný orð en jafnaldrar peirra með dæmigerðan málproska (McGregor o.fl., 2013). Pau einskorða sig við algeng orð í tali og nota sjaldan fátíð orð prátt fyrir að pekkja pau (Nation og Snowling, 2004). Gera má ráð fyrir að pau purfi að heyra nýtt orð a.m.k. tvisvar sinnum oftar en börn með dæmigerðan málproska áður en pau skilja orðið og nota upp á eigin spýtur (Paul o.fl., 2018). McGregor o.fl. (2013) fylgdust með breytingum á orðaforða 502 barna með málproskaröskun. 
Dau voru prófuð í öðrum, fjórða, áttunda og tíunda bekk og athugað hversu mörg orð pau gátu nefnt (stærð orðaforðans) og hversu vel pau skilgreindu hvert orð (dýpt orðaforðans). Niðurstöður bentu til pess að börn á skólaaldri með málproskaröskun hefðu almennt minni orðaforða en jafnaldrar peirra með dæmigerðan málproska. Orðaforði pátttakenda reyndist takmarkaður, bæði hvað varðar stærð og dýpt og hélst munurinn alla skólagönguna.

Pá hefur einnig verið sýnt fram á að börn með málproskaröskun eiga í erfiðleikum með margræðni orða og myndmál. Dau njóta pess síður að láta lesa fyrir sig og með pví missa pau af tækifæri til að læra ný orð og tileinka sér málfræði og setningagerð sem kemur fram í sögubókum (Paul o.fl., 2018).

Degar talað er um orðaforða barna er óhjákvæmilegt að minnast á lestur (e. reading) en bein tengsl eru á milli orðaforða og lesskilnings (Paul o.fl., 2018). Börn purfa að skilja merkingu orða og setninga sem pau lesa til að ná samhengi og skilja textann. Laufer og Ravenhorst-Kalovski (2010) sýndu að nemendur í framhaldsskóla pyrftu að pekkja 98\% orða í texta til að geta skilið hann og tileinkað sér án utanaðkomandi aðstoðar. Fari pessi tala niður í 95\% purfa flestir nemendur aðstoð, til dæmis orðabók, til að skilja textann.

\section{Að kenna eða læra ný orð}

Ýmsar leiðir eru árangursríkar til að auka orðaforða barna. Meðalbarn lærir merkingu mörg hundruð orða á ári, pótt pað geti verið gríðarlegur einstaklingsmunur á hvað börn pekkja mörg orð. Ný orð lærast oft í samræðum og í samskiptum við aðra (Rice, Buhr og Nemeth, 1990). Börn með slakan orðaforða við upphaf skólagöngu purfa að bæta við sig nokkur hundruð orðum aukalega á ári til að eiga möguleika á að ná jafnöldrum sínum (Biemiller og Boote, 2006).

Í safngreiningu (e. meta-analysis) Marulis og Neuman (2010) skoðuðu peir 67 rannsóknir á orðaforðakennslu ungra barna. Í pessum rannsóknum var algengast að nota sögulestur eða hliðstæða aðferð sem nefnd er samræðulestur (e. dialogic reading) til að auka orðaforða barna og orðanám barnanna borið saman með beinni kennslu annars vegar og óbeinni kennslu hins vegar. Deirra niðurstaða var að bein kennsla, með pví að útskýra markorð sérstaklega, væri árangursrík leið til að auka orðaforða barna. Dessi aðferð var talin árangursríkari en óbein kennsla par sem reiknað var með að börn lærðu merkingu orða út frá samhengi. Einnig gafst vel að blanda saman beinni og óbeinni kennslu pannig að markorðin voru fyrst lesin í samhengi og síðan útskýrð beint, rifjuð upp og unnið með pau sérstaklega í verkefnum. Aðrar rannsóknir hafa einnig sýnt jákvæð áhrif beinnar kennslu (Beach, Sanchez, Flynn og O’Connor, 2015; Biemiller og Boote, 2006; McKeown og Beck, 2014). Hugmyndafræði beinnar kennslu kom fyrst fram á sjónarsviðið í byrjun níunda áratugar 20. aldar. Fyrst var aðferðin sérstaklega hugsuð fyrir börn á grunnskólaaldri (Beck, Perfetti og McKeown, 1982; McKeown, Beck, Omanson og Perfetti, 1983; McKeown, Beck, Omanson og Pople, 1985) en í byrjun 21. aldar var aðferðin aðlöguð að leikskólabörnum (Beck og McKeown, 2007).

Í safngreiningu Marulis og Neuman (2010) var tímalengd, tímafjöldi og lengd hvers íhlutunartíma einnig athuguð. Ekki fékkst einhlít niðurstaða um hvað væri árangursríkast enda fjölmargar breytur sem komu við sögu. Áhrifastærð (e. effect size) voru til dæmis meiri ef pjálfunin tók styttri tíma í vikum talið og ef tímar voru fáir. Degar skoðuð var lengd hvers pjálfunartíma kom 1 ljós að lengri tímar voru ekki árangursríkari en styttri. Djálfunartími sem var styttri en 20 mínútur, að lágmarki 7 mínútur, gaf ekki marktækt verri niðurstöðu en lengri tími.

Riches, Tomasello og Conti-Ramsden (2005) athuguðu hversu fljótt og vel börn með sértæka málproskaröskun tileinkuðu sér nýjar sagnir og báru saman við samanburðarhóp með eðlilegan málproska. Dau komust að pví að börn með sértæka málproskaröskun purftu bæði að heyra nýja orðið oftar og yfir lengri tíma en börn í samanburðarhópnum. Enn fremur var börnum með sértæka málproskaröskun hættara við að gleyma orðunum eftir að íhlutun lauk. 
Í skýrslu National Reading Panel (National Institute of Child Health and Human Development, 2000) var einkum prennt sem talið var árangursríkt við að auka orðaforða barna; í fyrsta lagi að nota sjónrænan stuðning, í öðru lagi að heyra orð endurtekið og í priðja lagi að kenna orð í fjölbreyttu samhengi. Sögulestur gefur möguleika á að nýta alla pessa pætti. Auðvelt er að endurtaka með pví að lesa sömu bók aftur og aftur og ræða um ákveðin orð, sögubækur fyrir yngri börn eru yfirleitt mikið myndskreyttar sem getur nýst sem sjónrænn stuðningur og orð koma fyrir í fjölbreyttu samhengi sem getur dýpkað skilning á merkingu peirra.

\section{Orðaforðakennsla með sögulestri}

Niðurstöður rannsókna sýna að hægt sé að auka orðaforða barna með pví að lesa fyrir pau sögur (Walsh og Blewitt, 2006; Wasik og Bond, 2001). Rannsóknir á málfærni íslenskra leikskólabarna hafa sýnt að börn sem oft er lesið fyrir búa yfir ríkulegri orðaforða en pau sem sjaldan er lesið fyrir (Hrafnhildur Ragnarsdóttir, 2015) og börn sem lesið er fyrir daglega hafa betri mál- og hljóðvitund en börn sem lesið er sjaldnar fyrir (Amalía Björnsdóttir, Ingibjörg Símonardóttir og Jóhanna Einarsdóttir, 2003).

Áhrif sögulestrar á orðanám barna hafa verið skoðuð í mismunandi útfærslum í mörgum rannsóknum (Beck, McKeown og Kucan, 2013; Biemeller og Boote, 2006; Coyne, McCoach og Kapp, 2007; Wilkinson og Houston-Price, 2013). Aðferðin Orðaspjall hefur verið próuð fyrir íslenska leikskóla (Árdís Hrönn Jónsdóttir, 2013) og byggist á aðferð Beck o.fl. (2013) um markvissa kennslu orða með sögulestri. Markmiðið er að efla skilning barna á samfelldum texta og auka orðaforða peirra með markvissum hætti. Kennari les sögubók með börnunum og útskýrir merkingu orða sem koma fyrir í bókinni. Eftir lesturinn fer kennarinn yfir sögupráđinn og hvetur börnin til að velta sögunni fyrir sér með samræðum um bókina. Við val á orðum er stuðst við flokkun Beck o.fl. (2013) á premur mismunandi lögum orðaforðans (e. three tier model of vocabulary words). Algeng orð úr talmáli sem purfa sjaldnast sérstaka kennslu eru í fyrsta lagi orðaforðans (e. tier one). Petta eru orð sem flokkast undir grunnorðaforða líkt og sofa, maður, lítill, ég. Algeng orð í ritmáli og námsbókum eru í millilagi orðaforðans (e. tier two). Detta eru oft sjaldgæfari orð sem eru notuð yfir algeng hugtök, líkt og lúinn í stað preyttur og kjökra í stað gráta. Í priðja laginu (e. tier three) eru sjaldgæf og sértæk orð sem koma einkum fyrir á tilteknum sérsviðum, t.d. í vísindum, tæknifræði og atvinnugreinum. Má par nefna orð líkt og móberg, málproskafrávik og meðaltal. Í Orðaspjalli eru valin orð úr millilagi orðaforðans til að útskýra sérstaklega.

Biemiller og Boote (2006) báru saman aðferð beinnar kennslu og óbeinnar við að auka orðaforða grunnskólabarna með sögulestri. Dar var bók lesin endurtekið og annars vegar kannað hversu vel börnin tileinkuðu sér markorð sem voru útskýrð beint og hins vegar án beinnar útskýringar. Rannsóknin stóð yfir í eina viku og voru valin 24 markorð fyrir hvern aldurshóp. Að meðaltali náðu börnin merkingu 12\% markorðanna með pví að heyra orðin endurtekið en peim fjölgaði upp í $22 \%$ við að fá beina útskýringu á peim. Rannsóknin var síðan endurtekin ári seinna með fleiri pátttakendum og pá voru öll orð útskýrð sem talið var að börnin skildu ekki. Seinni rannsóknin sýndi betri árangur en sú fyrri. Börnin lærðu pá að meðaltali 40\% af markorðunum. Coyne og félagar (2007) notuðu fyrrnefnda aðferð hjá börnum á leikskólaaldri (5-6 ára). Deir báru saman orðanám barna í skóla par sem stór hluti barna var í áhættu varðandi lestrarerfiðleika. Pátttakendum var skipt af tilviljun í tvo hópa og voru 3-4 í hvorum hópi. Rannsóknin tók eina viku. Hvor hópur heyrði söguna um grísina prjá lesna prisvar sinnum. Valin voru sex markorð (tvö nafnorð, tvö sagnorð og tvö lýsingarorð) úr sögunni sem póttu mikilvæg og ólíklegt að börnin pekktu. Prjú orð voru kennd með beinni útskýringu með pví að kynna pau sem töfraorð áđur en lesturinn hófst. Degar eitthvert markorðanna kom síðan fyrir í setningu var hún lesin aftur og orðið útskýrt, hvort sem börnin tóku eftir pví eða ekki. Eftir söguna var flett í gegnum bókina og markorðin rifjuð upp, pau endurtekin og farið yfir hvernig pau komu fyrir í sögunni. Prjú orð voru ekki kennd sérstaklega og pá var sagan lesin án pess að stöðva við markorðin eða kynna pau til leiks. Niðurstöður rannsóknarinnar sýndu að börnin lærðu marktækt fleiri orð 
með beinni kennslu en með óbeinni kennslu og var sú kunnátta enn til staðar átta vikum eftir að íhlutun lauk.

Tvær rannsóknir hafa verið gerðar á Íslandi par sem könnuð voru áhrif beinnar kennslu með sögulestri á orðskilning fimm ára tvítyngdra barna. Báðar sýndu að börnin lærðu mun fleiri markorð sem voru útskýrð beint en samanburðarorð sem ekki voru útskýrð (Eyrún Rakel Agnarsdóttir, 2018; Helga Hilmarsdóttir, 2016). Helga Hilmarsdóttir (2016) sýndi enn fremur að pátttakandinn í hennar rannsókn viðhélt pekkingu sinni á orðunum sem kennd voru með beinni kennslu mánuði eftir að rannsókninni lauk. Aðferðin hefur hins vegar ekki áður verið skoðuð með börnum sem purfa á sérstakri örvun að halda og eru á eftir í málproska.

\section{Rannsóknarspurningar}

Markmið rannsóknarinnar var að skoða aðferð til að auka orðaforða hjá tveimur börnum með málproskaröskun í elsta árgangi î leikskóla og meta árangurinn af peirri kennslu. Hún fól í sér að útskýra fyrirfram ákveðin markorð pegar pau komu fyrir í sögubók og vinna með pau að lestri loknum. Leitast var við að svara eftirfarandi spurningum:

- Skilar bein útskýring á markorðum, ásamt kennslu að lestri loknum, betri árangri til að auka orðaforða barnanna en að fá enga útskýringu á markorðum?

- Ef orðaforðinn eykst, helst sú kunnátta að einhverju marki mánuði eftir að kennslu lýkur?

- Hefur orðaforðakennsla með lestri sögubóka áhrif á almenna máltjáningu barnanna eins og hún er metin með málsýnum?

\section{Aðferð}

\section{Pátttakendur}

Tveir pátttakendur voru í rannsókninni og uppfylltu peir eftirtalin skilyrði; 1) fæddir og aldir upp á Íslandi og á síðasta ári í leikskóla, 2) sýna slaka færni á málproskaprófinu TOLD-2P (1,5 staðalfrávik undir meðalgetu jafnaldra) og 3) sýna slaka færni á hljóð- og málvitundarprófinu HLJÓM-2. Valdir pátttakendur voru drengur og stúlka sem verða hér eftir kölluð Tómas og Eva en pað eru ekki peirra réttu nöfn. Börnin voru í sama leikskóla á höfuðborgarsvæðinu.

Tómas fæddist á Íslandi. Hann ólst upp við tvö tungumál, faðir hans talaði við hann íslensku en móðir hans talaði við hann spænsku sem var hennar fyrsta mál. Tómas virtist skilja einhverja spænsku en talaði hana ekki og svaraði á íslensku pegar móðir hans talaði við hann á spænsku. Íslenskan var hans sterkara tungumál. Fyrst fór að bera á málproskavanda Tómasar um priggja ára aldur en athuganir með málbroskaprófum sýndu pá slaka færni eða málbroskatölu sem var tæpum 2 staðalfrávikum undir meðalgetu jafnaldra. Niðurstöður á HLJÓM-2 við fimm ára aldur sýndu mjög slaka færni og einnig niðurstöður TOLD-2P. Starfsfólk leikskólans taldi að Tómas ætti í erfiðleikum með að fylgjast með í samverustundum og tók rannsakandi (fyrsti höfundur greinarinnar) sjálfur eftir pví pegar hann fylgdist með Tómasi í slíkri stund par sem saga var lesin. Tómas truflaði ekki mikið heldur virtist hann vera annars hugar og ekki fylgjast með pví sem fram fór. Tómas fellur samkvæmt skilgreiningu undir að vera með málproskaröskun par sem hann sýnir veruleg frávik í báđum peim tungumálum sem eru til staðar í umhverfi hans. Tómas var 6 ára pegar íhlutunin átti sér stað.

Eva er einnig fædd á Íslandi og á íslenska foreldra. Niðurstöður á málproskaprófinu TOLD-2P pegar Eva var um fimm ára gömul sýndu færni sem var 1,5 staðalfrávikum undir meðalgetu jafnaldra. Ennfremur sýndu niðurstöður athugunar með HLJÓM-2 slaka færni. Starfsfólk leikskólans taldi að Eva ætti í erfiðleikum með tungumálið. Degar rannsakandi fylgdist með Evu í sögustund virtist hún eiga erfitt með að sitja kyrr og hlusta á söguna. Yfirleitt fór hún að gera eitthvað annað, fiktaði í hlutum sem hún hafði meðferðis eða reyndi að trufla sessunaut sinn. Eva var rúmlega 5 ára og 6 mánaða pegar íhlutunin fór fram. 


\section{Mælingar}

Mælingar voru gerðar með sérhönnuðu orðaforðaprófi og með málsýnum. Auk pess var meðferðarheldni (e. fidelity) mæld sérstaklega. Með meðferðarheldni er átt við hvort rannsóknin hafi verið framkvæmd eins og ákveðið var í upphafi, sjá nánar síðar.

Í Töflu 1 sést yfirlit yfir pær mælingar sem gerðar voru.

Tafla 1. Yfirlit yfir mælingar gerðar meðan á rannsókninni stóð.

\begin{tabular}{ll}
\hline Tími mælinga & Mælitæki \\
\hline Mælingar á grunnskeiði & $\begin{array}{l}\text { Sérhannað mælitæki, alls 36 orð } \\
\text { Málsýni }\end{array}$ \\
\hline $\begin{array}{l}\text { Daglegar mælingar eftir hvern } \\
\text { kennslutíma }\end{array}$ & $\begin{array}{l}\text { Orð dagsins (markorð eða samanburðarorð), } \\
\text { alls } 6 \text { orð mæld með sérhönnuðu mælitæki }\end{array}$ \\
Vikulegar mælingar & Málsýni \\
Mælingar um leið og kennslu lauk & $\begin{array}{l}\text { Sérhannað mælitæki, alls 36 orð } \\
\text { Málsýni }\end{array}$ \\
Mælingar mánuði eftir að kennslu lauk & $\begin{array}{l}\text { Sérhannað mælitæki, alls 36 orð } \\
\text { Málsýni }\end{array}$ \\
\hline
\end{tabular}

\section{Sérhannað mælitæki}

Útbúið var sérhannað mælitæki til að prófa úr markorðaforðanum sem var alls 36 orð, 18 markorð sem voru útskýrð sérstaklega og 18 orð sem ekki voru útskýrð. Byggt var á rannsókn Coyne og félaga (2007) við hönnun mælitækisins. Mælingar voru fyrir íhlutun, strax eftir íhlutun og að lokum mánuði síðar pegar viðhaldsmælingar voru gerðar, sjá Töflu 1. Daglega var spurt um markorðin sex sem tengdust peirri bók sem lesin var hverju sinni.

Prófun úr markorðaforðanum fór pannig fram að rannsakandi spurði barnið Hvað pýðir X? eða Hvað er X? Dæmi: Hvað pýdir kroppur? eða Hvað pýdir að vera sorgmaeddur? Tvö stig fengust fyrir rétt svar eins og rannsakandi hafði fyrirfram skilgreint pað. Eitt stig fékkst ef barnið sagði einhvern hluta orðsins rétt eða benti. Sem dæmi orðið kroppur, en pá fékk barnið eitt stig ef pað benti á einhvern líkamshluta eða nefndi a.m.k. tvo líkamshluta. Dar sem sérhannaða mælitækið var gert sérstaklega fyrir pessa rannsókn var ekki um stöðluð svör að ræða og var pað mat rannsakanda hvað teldist rétt og hvað rangt. Öll svör barnsins voru skráð og farið var yfir fyrirgjöf. Fyrir markorðin 36 var mest hægt að fá 72 stig. Til að gera prófunina meira aðlaðandi fyrir börnin skrifaði höfundur orðin á miða, setti pá í skál og börnin drógu af tilviljun og útskýrðu.

\section{Málsýni}

Málsýni (e. language sample) eru óformlegar athuganir á málproska barna og stutt sýnishorn af máltjáningu barns í samtali við aðra. Pau eiga að sýna dæmigerða máltjáningu barnsins við eðlilegar aðstæður og eru mjög oft notuð samhliða stöðluðum prófum. Málsýni eru oft notuð til að mæla árangur af íhlutun par sem hægt er að taka pau endurtekið. Við úrvinnslu málsýna eru notaðar eftirtaldar mælieiningar: Meðallengd segða (MLS), fjöldi mismunandi orða (FMO), heildarfjöldi orða (HFO) og hlutfall villna. Tali barnanna var skipt í segðir (e. utterance) eftir ákveðnum reglum og er ein segð oftast sambærileg einni setningu Í pessari rannsókn verður stuðst við mælieiningarnar FMO og hlutfall villna. FMO gefur mynd af fjölbreytileika í orðanotkun barna í sjálfsprottnu tali og við hlutfall villna er skoðað hversu mörg orð eru málfræðilega rangt mynduð. (Jóhanna Thelma Einarsdóttir og Póra Sæunn Úlfsdóttir, 2018). Viðmiðunartölur eru 
til fyrir pessar mælingar og miða pær við 50 segðir barns. Viðmiðunartölur voru fengnar frá 39 börnum í aldurshópnum 5;6 til 5;11 og frá 25 börnum í aldurshópnum 6;0 til 6;5 ára. Stuðst er við meðaltal en pess ber að geta að staðalfrávik innan hvers aldurshóps fyrir FMO er hátt og ekki hefur verið gefið upp staðalfrávik fyrir hlutfall villna (Jóhanna T. Einarsdóttir og Álfhildur Porsteinsdóttir, 2015).

Samtals voru 13 málsýni tekin frá hvoru barni sem skiptust pannig að prjú voru tekin áđur en kennsla hófst, sex voru tekin í lok hverrar viku, prjú að kennslu lokinni og að lokum eitt pegar viðhaldsmælingar voru gerðar mánuði eftir að kennslu lauk. Málsýnin voru tekin við leik og í samtali rannsakanda og pátttakenda. Pau voru tekin upp (hljóð og mynd) með iPhone 7 síma og afrituð samkvæmt handbók um málsýni (Jóhanna Thelma Einarsdóttir og Póra Sæunn Úlfsdóttir, 2018). Hugbúnaðurinn Málgreinir (Jóhanna Thelma Einarsdóttir og Stefán Carl Peiser, 2016) var notaður til að reikna út fjölda mismunandi orða (FMO) og hlutfall villna.

\section{Efni}

Við kennsluna voru notaðar sögubækur sem voru valdar pannig að pær væru ekki of langar par sem aðeins var gert ráð fyrir að hámarki 30-40 mínútum í hvern kennslutíma. Pá pótti einnig mikilvægt að gæta pess að bækurnar væru ekki of erfiðar og að líklegt væri að börnunum pættu pær skemmtilegar og myndu vekja áhuga peirra. Sex bækur voru notaðar í kennslunni.

Val á orðum

Valin voru sex markorð úr hverri bók, tvö nafnorð, tvö sagnorð og tvö lýsingarorð. Samtals voru markorðin pví 36 úr bókunum sex. Af peim fengu börnin beina útskýringu á 18 orðum en hin 18 voru ekki útskýrð og notuð til samanburðar. Við val á orðum var farið í gegnum hverja bók og fundin sex orð út frá viðmiðun Beck og félaga (2013) um millilag orðaforðans. Í beinni kennslu voru markorðin kennd um leið og pau komu fyrir í textanum og stutt verkefni gerð í lokin en í óbeinni kennslu voru samanburðarorð ekki kennd. Markmiðið með samanburðarorðunum var að kanna hvort pekking barnanna á orðunum ykist með pví að heyra pau í samhengi eða hvort beina orðaforðakennslu pyrfti til og að heyra orðin endurtekið. Markorðin voru skilgreind með aðstoð orðabókar og skilgreiningarnar aðlagaðar að aldri barnanna. Útskýring til dæmis á markorðinu ástúð var að pykja vænt um einhvern. Dæmi: Dér pykir vænt um mömmu pína. Í Töflu 2 má sjá upplýsingar um markorð og samanburðarorð úr hverri bók.

Tafla 2. Bækur, markorð/samanburðarorð og kennsluaðferð.

\begin{tabular}{|c|c|c|}
\hline Bók & Markorð og samanburðarorð & $\begin{array}{l}\text { Bein eða óbein } \\
\text { kennsla }\end{array}$ \\
\hline Konungsborna bólubaslið & $\begin{array}{l}\text { Kollur, dónaskapur, kjökra, kemba, } \\
\text { fjarlogd, sorgmaeddur. }\end{array}$ & Bein kennsla \\
\hline Búkolla & $\begin{array}{l}\text { Ástúd, bál, maela, míga, ógnarstór, } \\
\text { stórstíg. }\end{array}$ & Bein kennsla \\
\hline Letipúkar & $\begin{array}{l}\text { Kroppur, hrúga, nenna, spjalla, } \\
\text { varlega, snöggur. }\end{array}$ & Bein kennsla \\
\hline $\begin{array}{l}\text { Stór og svolítið pirrandi } \\
\text { fíll }\end{array}$ & $\begin{array}{l}\text { Líkamsrakt, blundur, troðast, } \\
\text { mölbrjóta, harkalega, risavaxinn. }\end{array}$ & Óbein kennsla \\
\hline Fjörugt ímyndunaraf1 & $\begin{array}{l}\text { Félagsskapur, öngpveiti, háma, } \\
\text { kremja, glorhungraður, undrandi. }\end{array}$ & Óbein kennsla \\
\hline Gleym-mér-ei & $\begin{array}{l}\text { Hjöro, sólsetur, skrcekja, mása, } \\
\text { dýrmatt, hugrakkur. }\end{array}$ & Óbein kennsla \\
\hline
\end{tabular}




\section{Rannsóknarsnið}

Við greiningu gagna var notað snið margpætts grunnskeiðs (e. multiple-baseline design) sem er ein tegund af einliðasniði (e. single-subject design). Раð er notað til að skoða sams konar hegðun hjá nokkrum einstaklingum með pví að beita íhlutun á ólíkum tímum (Guðrún Árnadóttir og Dorlákur Karlsson, 2003; Kazdin, 2011). Fyrstu vikuna fengu hvorki Tómas né Eva kennslu, p.e. bækurnar voru lesnar án pess að staldra nokkuð við ákveðin orð. Í annarri og priðju viku fékk Tómas kennslu en ekki Eva. Í fjórðu viku fengu hvorki Tómas né Eva kennslu. Í fimmtu og sjöttu viku fékk Eva kennslu en Tómas ekki. Á Mynd 1 má sjá yfirlit um snið margpætts grunnskeiðs eins og pví var beitt í rannsókninni.

\section{Tómas}

\begin{tabular}{|c|c|c|c|c|c|}
\hline Vika 1 & Vika 2 & Vika 3 & Vika 4 & Vika 5 & Vika 6 \\
\hline Engin îhlutun & filutun & Îlutun & Engin ihlutun & Engin ihlutun & Engin ihlutun \\
\hline
\end{tabular}

\section{Eva}

\begin{tabular}{|l|l|l|l|l|l|}
\hline Vika 1 & Vika 2 & Vika 3 & Vika 4 & Vika 5 & Vika 6 \\
\hline & & & & & \\
\hline Engin ihlutun & Engin ihlutun & Engin inlutun & Engin ihlutun & Ihlutun & Iilutun \\
\hline
\end{tabular}

Mynd 1. Snið margpæetts grunnskeiðs í rannsókninni.

\section{Framkvæmd}

Íhlutunaraðferðin byggist á aðferð Coyne og félaga (2007). Rannsókninni var breytt pannig að pátttakendur voru færri og með skilgreinda málproskaröskun, rannsóknartíminn var lengdur, fleiri bækur voru notaðar og fleiri markord. Íhlutunin fór fram fjórum sinnum í viku yfir sex vikna tímabil í litlu sérkennsluherbergi á leikskóla barnanna og var rætt við eitt barn í senn. Við beina kennslu tók hver tími um 30-40 mínútur en við óbeina kennslu var hver tími aðeins um 15 mínútur.

Í hverri viku voru lesnar prjár bækur en par sem íhlutunin var fjórum sinnum í viku var sama bókin lesin tvisvar, til dæmis á mánudegi og svo aftur á fimmtudegi. Líkt og í rannsókn Coyne og félaga (2007) voru markorðin kynnt fyrir barninu áđur en lesturinn hófst og talað um að petta væru töfraorð. Barnið var beðið um að veita peim eftirtekt pegar pau kæmu fyrir í sögunni. Ef barnið tók eftir orðinu var setningin lesin aftur og útskýring gefin á markorðinu. Ef barnið tók ekki eftir orðinu var útskýringin samt sem áður gefin og setningin lesin aftur. Dæmi: Ef barnið tók eftir pví að orðið sorgmadd kom fyrir í sögunni var sú setning lesin aftur og orðið útskýrt á eftirfarandi hátt: Sorgmaeddur pýðir að vera mjög leiður eða dapur. Farið var yfir öll markorðin á sama 
hátt og sagan lesin til enda. Eftir hverja sögu var flett í gegnum bókina, markorðin rifjuð upp og unnið lítið verkefni sem fólst í að ræða um markorðin, útskýra pau aftur og barnið teiknaði pað sem gerðist í sögunni pegar hvert orð kom fyrir. Að lokum var rætt stuttlega í hvers konar aðstæðum merking orðsins gæet komið fyrir. Pannig var hvert markorð útskýrt aftur. Við óbeina kennslu voru bækurnar lesnar án pess að staldra við markorðin og engin verkefni voru í lok tímans. Par var verið að kanna hvort börnin áttuðu sig á merkingu orðanna með pví að heyra pau í samhengi við textann í sögunni. Pá heyrðu börnin ekki markorðin endurtekin eins og við beina kennslu.

\section{Meðferðarheldni}

Meðferðarheldni var könnuð með fjórum mælingum. Dær voru: Magn íhlutunar (e. dosage), fastheldni (e. adherence), gæði meðferðar (e. quality) og svörun (e. responsiveness). Hver pessara mælinga er mikilvæg til að útskýra og sýna á trúverðugan hátt hvað skilar árangri í rannsókninni (Dusenbury, Brannigan, Falco og Hansen, 2003).

Magn íhlutunar felur í sér mælingu á fjölda raunverulegra skipta sem íhlutun er veitt, lengd hvers skiptis og fjölda daga/vikna sem íhlutun er veitt. Fastheldni er skilgreind sem mælikvarði á hvort íhlutunin var veitt af nákvæmni. Fastheldni var könnuð hér með bví að mæla á priggja punkta kvarða hvort rannsakandi útskýrði markorðin eins og lagt var upp með í beinni kennslu. Einnig var kannað hvort rannsakandi sleppti útskýringu á samanburðarorðunum begar óbein kennsla fór fram. Kvarðinn var pannig að 1 stóð fyrir ekki viðunandi, 2 stóð fyrir gerir stundum og 3 stóð fyrir viðunandi. Gæði íhlutunar segja til um hversu vel henni var komið til skila eða hversu vel rannsakandinn kom íhlutuninni frá sér og hvernig samskipti rannsakanda og pátttakenda voru. Gæði rannsóknarinnar voru könnuð með pví að horfa til pess hvort rannsakandi læsi bókina og útskýrði markorðin pannig að hann næði athygli barnanna og sýndi að hann væri að leggja sig fram. Niðurstöðurnar voru einnig skráðar á sama priggja punkta kvarða og í mælingunni á fastheldni. Að lokum var svörun við íhlutun athuguð en hún vísar til pess hversu vel pátttakandi brást við íhlutuninni og einnig var skoðað að hve miklu leyti pátttakendur tóku pátt og hvort peir voru virkir pátttakendur í kennslunni. Svörun var mæld í rannsókninni með sama priggja punkta kvarða og metið hvort börnin höfðu ánægju af lestrinum eða ekki. Dessi mæling fól í sér að skoða pátttöku barnanna, út frá pví hvort pau tóku virkan pátt í umræðunni sem átti sér stað í íhlutuninni. Í pessari mælingu var stigagjöfin pannig að 1 stóð fyrir hlustar ekki, hefur ekki ánagju af lestrinum, 2 stóð fyrir hlustar með hálfum huga og 3 stóð fyrir hefur ánœegju af lestrinum og hlustar með athygli. Eftir að rannsókninni lauk horfði rannsakandi á öll myndböndin til að meta meðferðarheldni út frá mælingunum fjórum og óháður matsaðili var fenginn til að fara yfir 30\% myndbandanna til að meta hið sama. Að lokum voru niðurstöður bornar saman og samræmi skoðaðá milli rannsakandans og óháða matsaðilans.

\section{Niðurstöður}

\section{Sérhannað mælitæki - markorðaforði}

Próf úr öllum markorðaforðanum var lagt fyrir áður en kennslan hófst, strax eftir að henni lauk og um mánuði seinna. Fyrst verða niðurstöður skoðaðar hjá Tómasi og síðan hjá Evu.

Á Mynd 2 má sjá fjölda mark- og samanburðarorða sem Tómas kunni fyrir íhlutun, strax að henni lokinni og loks mánuði eftir að íhlutun lauk. Eins og sést á myndinni gat Tómas útskýrt mun fleiri markorð eftir íhlutun, bæði strax á eftir og mánuði síðar en fyrir hana, en paðátti ekki við um samanburðarorðin. 


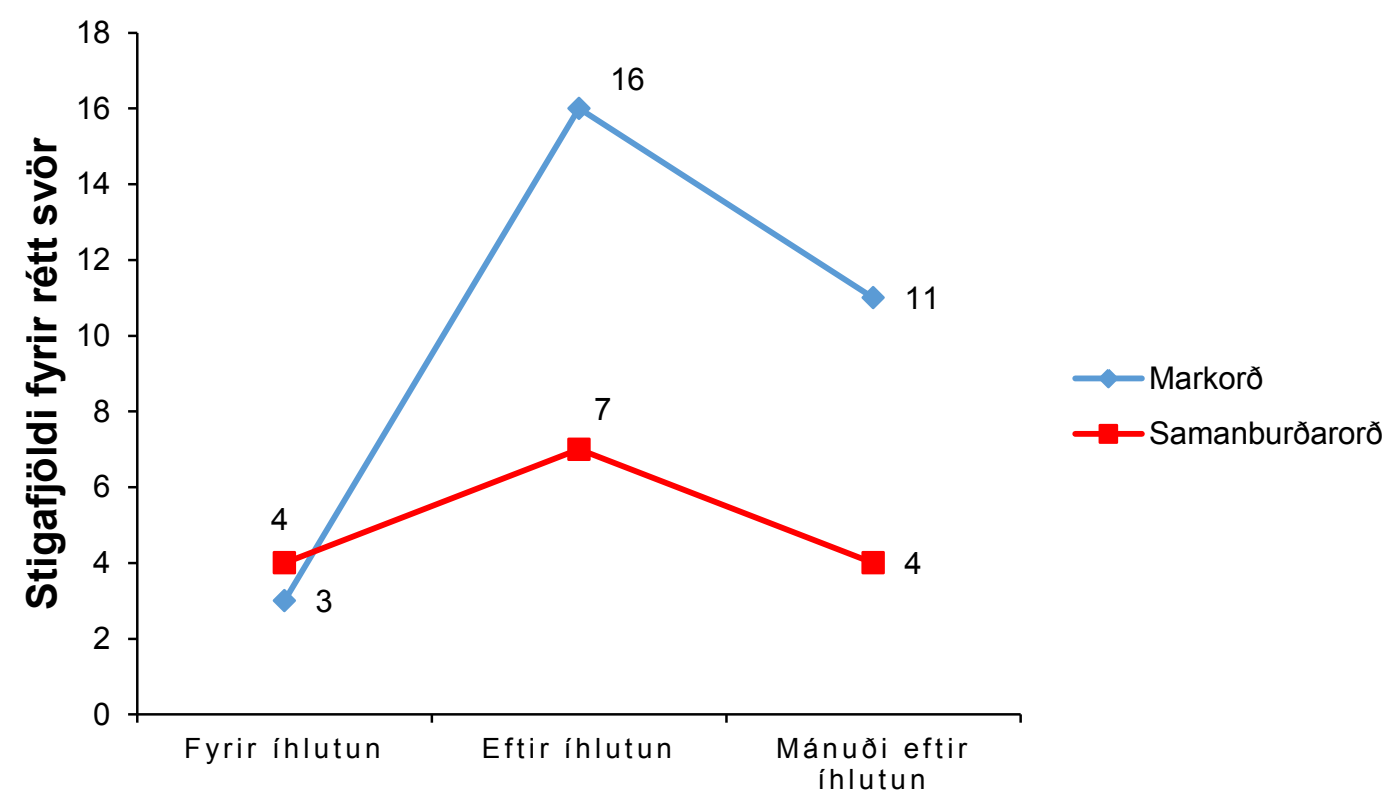

Mynd 2. Fjöldi réttra svara hjá Tómasi á markorðaforðaprófi fyrir íhlutun, eftir íhlutun og mánuði eftir íhlutun.

Á Mynd 3 má sjá fjölda mark- og samanburðarorða sem Eva kunni. Eins og sjá má á myndinni jókst kunnátta Evu strax eftir kennslu, bæði á markorðunum og samanburðarorðunum en kunnátta á markorðum sem kennd voru með beinni kennslu jókst meira en á orðum sem ekki var unnið með. Mánuði eftir að íhlutun lauk var Eva aftur prófuð úr markorðunum og hafði orðapekkingin ekki haldist að fullu en var pó mun betri en fyrir íhlutun.

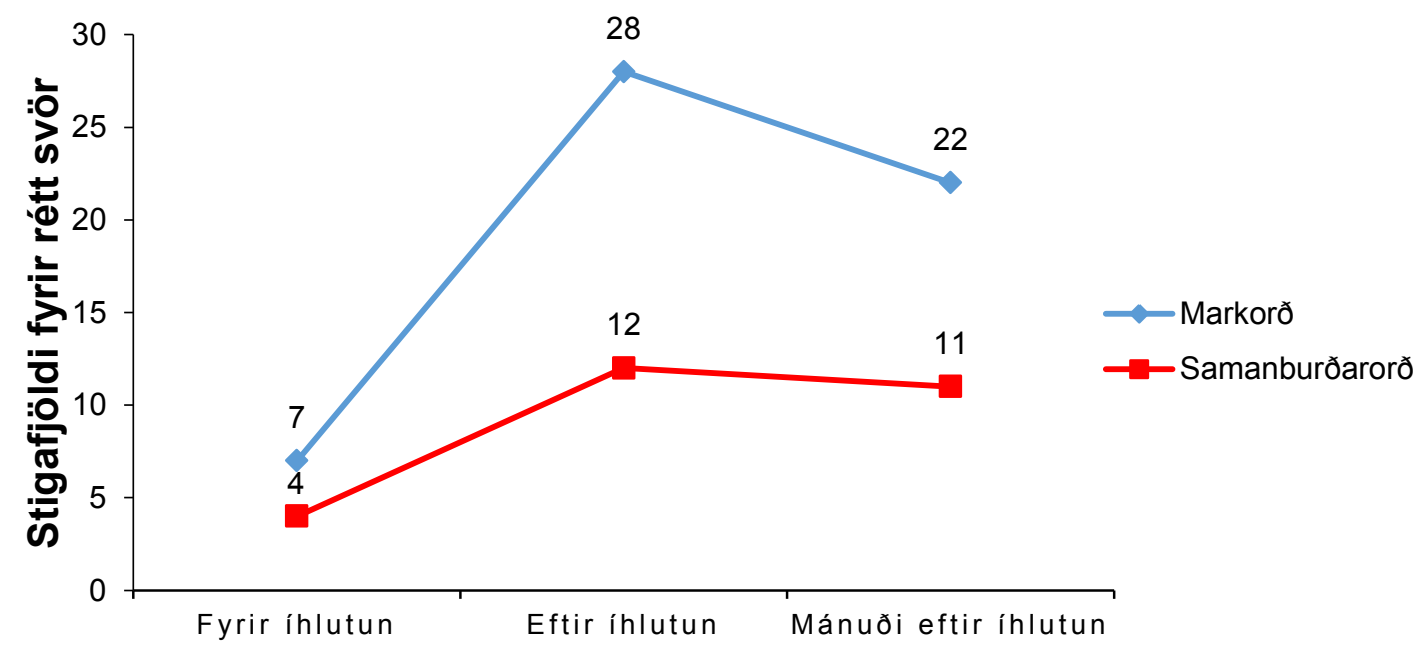

Mynd 3. Fjöldi réttra svara hjá Evu á markorðaforðaprófi fyrir íhlutun, eftir íhlutun og mánuði eftir íhlutun.

\section{Daglegar mælingar}

Á Mynd 4 má sjá niðurstöður daglegu mælinganna á pekkingu á markorðum, en pau voru sex talsins. Prófað var annaðhvort úr markorðunum sem voru ýmist útskýrð sérstaklega við beina kennslu eða ekki útskýrð við óbeina kennslu. Hjá Tómasi var grunnskeið fyrstu vikuna (á 1.-3. degi) og var pá sögubók lesin án útskýringar. Hann gat einu sinni svarað rétt til um eitt orð og fékk fyrir pað tvö stig. Í annarri og priðju viku (á 4.-9. degi) hófst svo íhlutun par sem farið var á markvissan hátt að kenna sex orð daglega með beinni kennslu. Á myndinni má sjá miklar 
framfarir. Í áttundu mælingu má sjá að Tómas náði að svara spurningum um öll markorðin rétt og fékk pá 12 stig. Í fjórðu til sjöttu viku (á 10.-18. degi) fór aftur fram óbein kennsla og orðin ekki útskýrð sérstaklega. Par má sjá að færnin féll aftur niður. Hjá Evu voru grunnskeiðsmælingar teknar fyrstu fjórar vikurnar (12 daga). Dá var lesin sögubók án útskýringa, b.e. óbein kennsla. Eins og sjá má á Mynd 4 fékk Eva 0-4 stig fyrir rétt svör í óbeinni kennslu á grunnskeiði, pannig að hún gat mest svarað rétt til um tvö orð. Síðustu tvær vikurnar (á 13.-18. degi) hófst íhlutun par sem Eva fékk beina kennslu á markorðunum. Par jókst kunnátta hennar smám saman og fékk hún 8-9 stig fyrir rétt svör síðustu fjóra dagana.

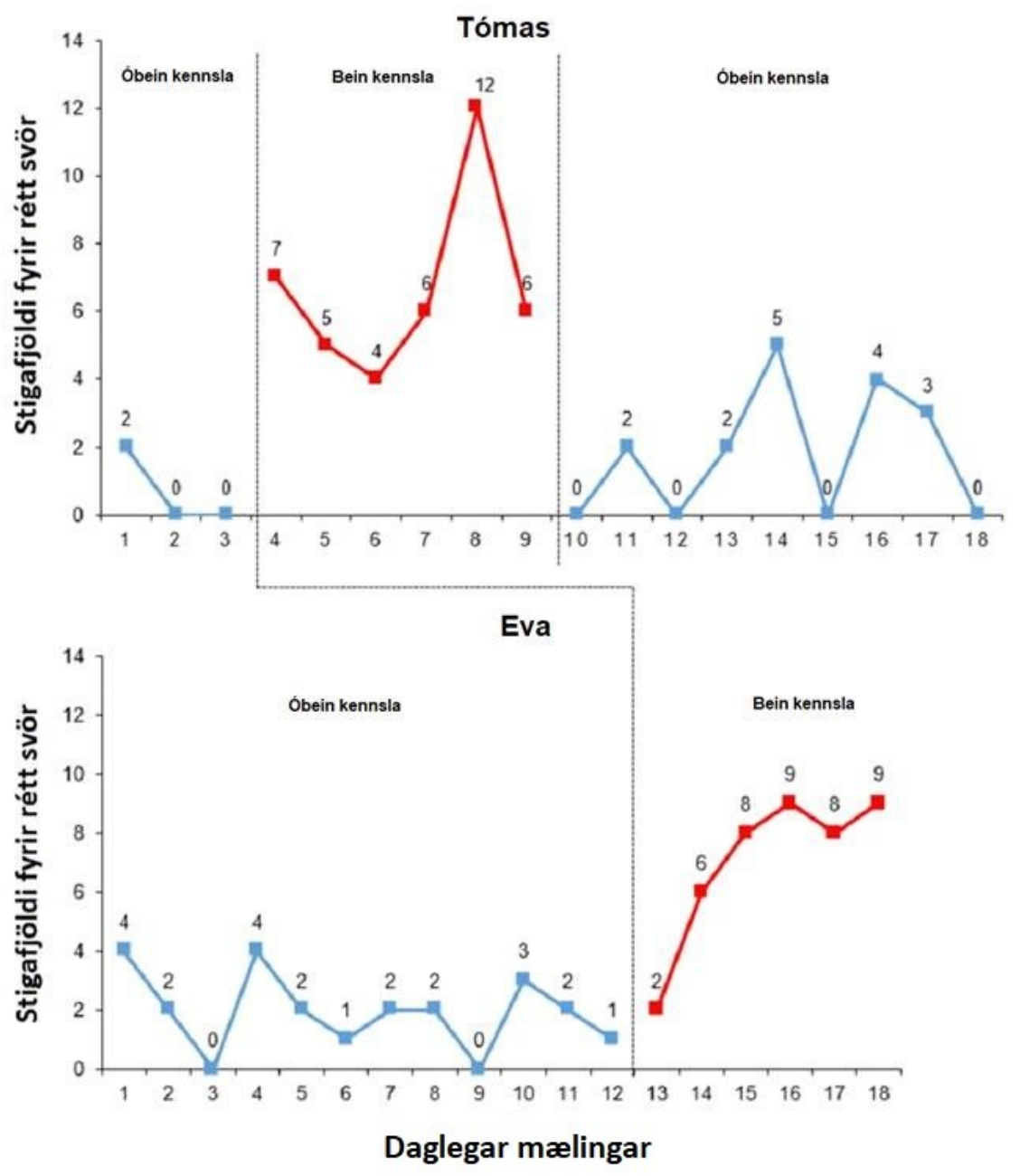

Mynd 4. Daglegar mælingar á markorðaforðaprófi hjá Tómasi og hjá Evu.

\section{Málsýni}

Samtals voru tekin 13 málsýni hjá hvoru barni. Mynd 5 sýnir fjölda mismunandi orða (FMO) hjá Tómasi. Eins og sést voru mælingar sveiflukenndar og ekki er hægt að segja að kennslan hafi haft áhrif á hversu fjölbreytileg orð Tómas notaði í sjálfsprottnu tali. Í 1., 5., 6., 9., 12. og 13. mælingu var Tómas um einu staðalfráviki fyrir neðan meðaltal jafnaldra (Jóhanna T. Einarsdóttir og Álfhildur Porsteinsdóttir, 2015). 


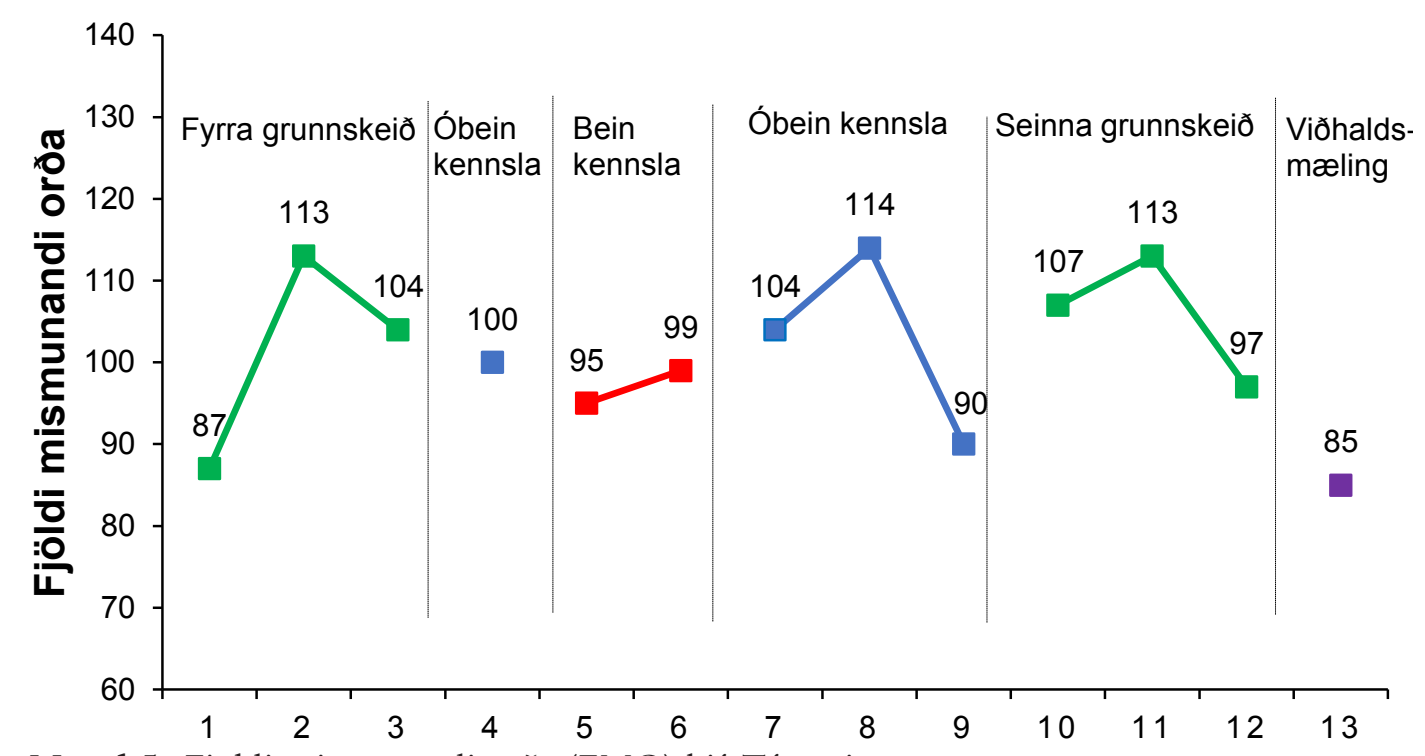

Mynd 5. Fjöldi mismunandi orða (FMO) hjá Tómasi.

Mynd 6 sýnir FMO hjá Evu. Hjá henni voru mælingar sömuleiðis nokkuð sveiflukenndar. FMO var undir meðaltali jafnaldra en pegar beina kennslan fór fram munaði einungis örfáum orðum að hún næði meðaltali barna í hennar aldurshópi (Jóhanna T. Einarsdóttir og Álfhildur Dorsteinsdóttir, 2015).

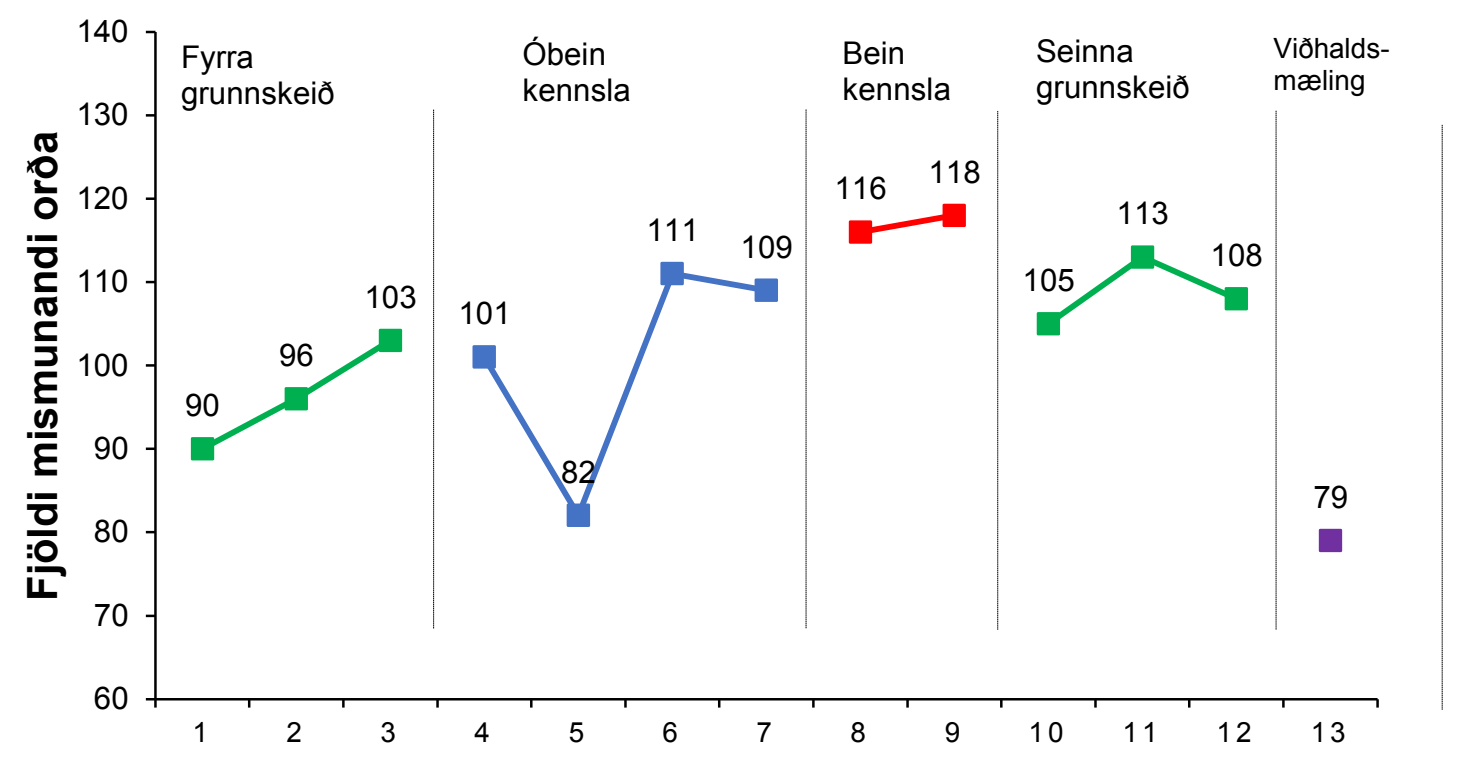

Mynd 6. Fjöldi mismunandi orða (FMO) hjá Evu.

Málfræðivillur voru mjög áberandi í tali barnanna og gerðu pau hlutfallslega mun fleiri villur en jafnaldrar að meðaltali. Dæmi um setningar sem Tómas myndaði eru: Núna áa allir að fara að borða, pau á bara að leika sér, við á svo fullt af dýrum og peir á að vinna í tjútjú lestinni. Í sjálfsprottnu tali hjá jafnöldrum Tómasar voru að meðaltali 1,3\% orða með villum (Jóhanna T. Einarsdóttir og Álfhildur Dorsteinsdóttir, 2015). Tómas gerði mun fleiri villur hlutfallslega í öllum mælingum. Kennslan virtist hins vegar hafa jákvæð áhrif á hlutfallslega tíðni villna á seinna grunnskeiði, en par gerði hann færri villur í sjálfsprottnu tali. Villum fjölgaði pó aftur í viðhaldsmælingunni. Mynd 7 sýnir hlutfallslegan fjölda villna hjá Tómasi meðan á rannsókninni stóð. 


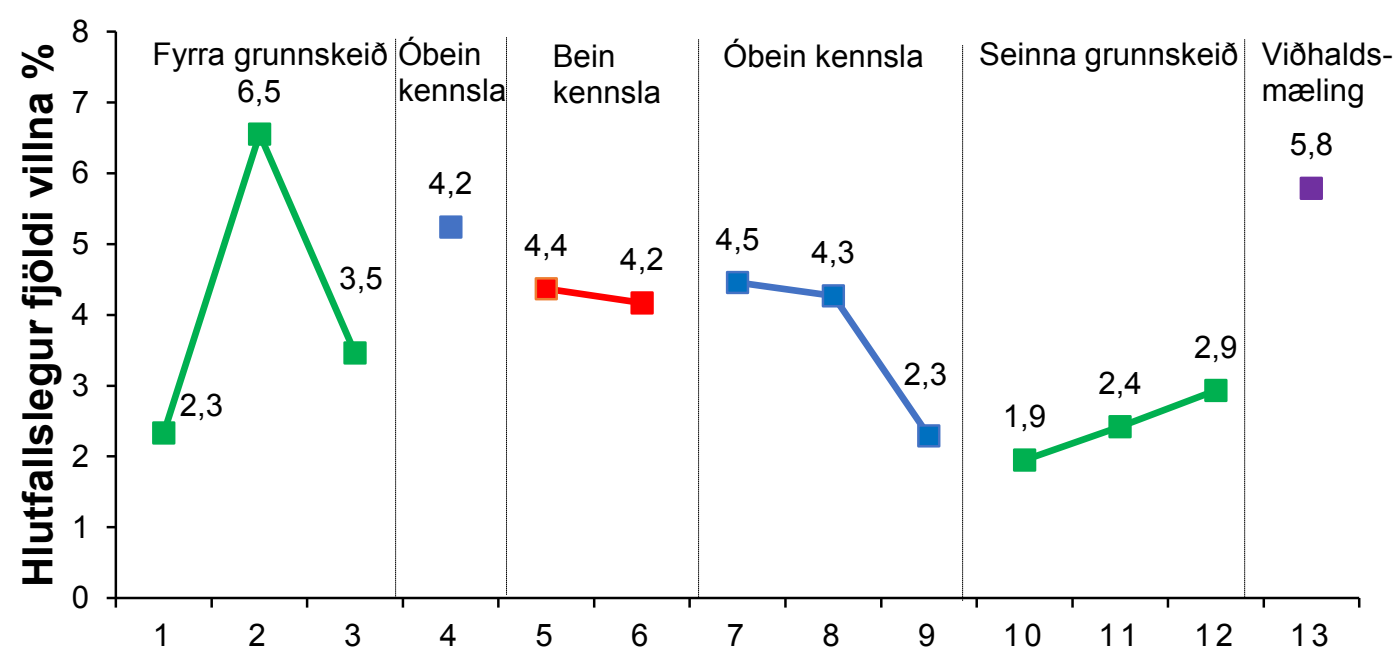

Mynd 7. Hlutfallslegur fjöldi villna (\%) hjá Tómasi.

Málfræðivillur voru einnig áberandi í tali Evu og sérstaklega átti hún í erfiðleikum með að beygja sagnir rétt. Pær voru oft óbeygðar og hafðar í nafnhætti eða rangt beygðar. Sem dæmi heyrðust setningar líkt og litla barnið sofa hér, ég má ekki brotna rúmið hennar. Einnig vantaði oft ord inn í setningar eða bygging setninganna var ófullkomin, samanber peir alltaf að vera í Star Wars, hann er litinn eins og petta. Mikil sveifla var í villufjölda á milli vikna hjá Evu. Kennslan virtist hafa jákvæð áhrif pannig að villur urðu pá færri í sjálfsprottnu tali. Hjá jafnöldrum Evu er hlutfallslegur fjöldi villna 1,6\% orða (Jóhanna T. Einarsdóttir og Álfhildur Porsteinsdóttir, 2015) og var Eva yfir pví meðaltali í öllum mælingunum nema tveimur, p.e. 5. og 9. mælingu. Mynd 8 sýnir hlutfall fjölda villna í málsýnum hjá Evu.

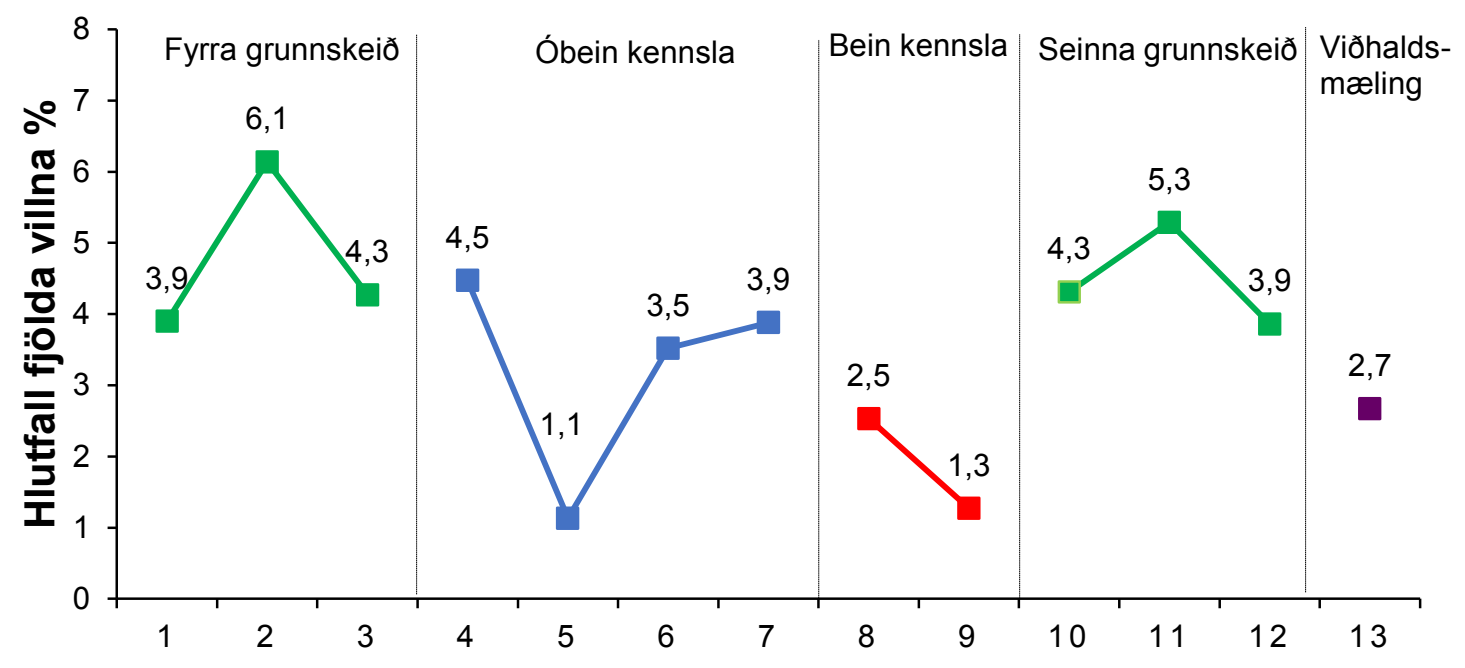

Mynd 8. Hlutfallslegur fjöldi villna (\%) hjá Evu.

\section{Meðferðarheldni}

Degar horft er til mælinga á magni íhlutunar var upphaflega gert rád fyrir 24 kennslutímum (fjöldi skipta) á hvort barn eða samtals 48 tímum. Vegna veikinda hjá börnunum náðist ekki að nota alla tímana en samtals var kennslutíminn $85,4 \%$ af ráðgerðum heildarkennslutíma hjá báðum börnum. Áxtluð tímalengd með beinni kennslu var 30 mínútur en 15 mínútur pegar óbein kennsla fór fram (lengd hvers skiptis). Meðaltal heildartíma með beinni kennslu var 26,8 
mínútur en 8,9 mínútur með óbeinni kennslu. Heildaríhlutunartími var 25 dagar eða 6 vikur. Niðurstöður fyrir fastheldni sýndu að í 100\% tilfella var hún viðunandi, pað sama átti við um gæði rannsóknarinnar en pau voru í 100\% tilfella viðunandi. Niðurstöður fyrir svörun sýndu að í 70,7\% tilfella höfðu börnin ánægju af lestrinum en pau hlustuðu með hálfum huga í 29,3\% tilfella.

Munur á mælingum rannsakanda og hins óháđa rannsóknaraðila var 0,85 mínútur eða 97\% samræmi $́$ athugunum á heildartíma kennslu. Í beinu kennslunni var munur upp á 0,11 mínútur eða 99\% samræmi fyrir heildartíma kennslunnar. Mælingar á fastheldni og gæðum rannsóknarinnar sýndu 100\% samræmi á milli matsmanna. Mælingar á svörun pátttakenda sýndu samræmi matsmanna upp á 95,7\% bæði fyrir ánægju af lestrinum og fyrir að hlusta með hálfum huga. Af pessum niðurstöðum má pví álykta að rannsakandinn hafi framkvæmt rannsóknina eins og upphaflega var lagt upp með jafnvel pó heildartími kennslu væri um 85\% af pví sem upphaflega var gert rád fyrir.

\section{Umræða}

Helstu niðurstöður rannsóknarinnar voru pær að með pví að lesa sögubók fyrir börnin tvö og kenna markorð með beinni kennslu ásamt kennslu að sögunni lokinni náðist góður árangur og pekking barnanna á markorðunum jókst umfram pekkingu peirra á samanburðarorðum. Lestur sögubóka án pess að útskýra markorðin sérstaklega hafði ekki sömu áhrif. Sú aukning á orðaforða sem átti sér stað í íhlutun hélst ekki að fullu mánuði eftir að henni lauk. Rannsóknin sýnir að við lestur sögubóka er mikilvægt að ræða um orð sem koma fyrir í textanum og útskýra pau. Orðaforðakennslan hafði ekki afgerandi áhrif á máltjáningu barnanna í sjálfsprottnu tali eins og hún var mæld með málsýnum en vísbendingar voru um að málfræðivillum færi fækkandi prátt fyrir að börnin tjáðu sig með jafn mörgum mismunandi orðum.

\section{Bein kennsla á markorðum}

Fyrsta rannsóknarspurningin fjallaði um hvort Tómas og Eva myndu læra fleiri markorð en samanburðarorð. Рað var metið með sérhönnuðu mælitæki sem var búið til fyrir pessa rannsókn og kannaði pekkingu barnanna á pessum orðum.

Prófun, sem var gerð fyrir og strax eftir íhlutun, staðfesti jákvæð áhrif beinnar kennslu. Tómas jók pekkingu sína á markorðunum sem voru útskýrð beint um 36,1\% en pekking hans á samanburðarorðunum jókst aðeins lítillega eða um 8,3\%. Eva náði einnig betur að tileinka sér markorðin sem voru kennd með beinni kennslu eða um 58,3\% við íhlutun samanborið við $22,2 \%$ við óbeina kennslu. Daglegar mælingar sýndu jákvæðari áhrif beinnar kennslu á orðaforða en óbeinnar kennslu. Nokkur atriði kunna að skýra pessi áhrif beinnar kennslu. Í fyrsta lagi voru orðin endurtekin og unnið með pau sérstaklega, í öðru lagi voru pau útskýrð beint og par með lærðu pátttakendur hvernig peir gætu útskýrt orðin og í priðja lagi tók beina kennslan um prisvar sinnum lengri tíma en óbeina kennslan. Niðurstöður erlendra rannsókna eru hliðstæðar og sýna að bein kennsla hefur jákvæðari áhrif á orðanám en óbein (Beck o.fl., 2013; Biemeller og Boote, 2006; Coyne o.fl., 2007) . Í skýrslu National Institute of Child Health and Human Development (2000) var m.a. nefnt að endurtekning og að kenna orð í fjölbreyttu samhengi væri árangursrík leið til að auka orðaforða barna. Samræmist pað aðferð beinnar kennslu við lestur sögubóka.

Dó að Marulis og Neuman (2010) hafi ekki getað sýnt fram á að lengd kennslutíma skipti höfuðmáli pegar verið er að auka orðaforða hjá ungum börnum er vel hugsanlegt að börn með málproskaröskun purfi lengri kennslutíma. Riches o.fl. (2005) komust einmitt að pví að börn með sértæka málproskaröskun purftu að heyra nýtt orð oftar og yfir lengri tíma en samanburðarhópur sem var ekki með málproskaröskun. Raunveruleg tímalengd íhlutunar, eins og hún var mæld í pessari rannsókn með ítarlegum mælingum á meðferðarheldni, er mjög mikilvægur páttur og oft vanmetinn í rannsóknum (Liebermann-Betz, 2015). 
Hvað varðar áhrif beinnar kennslu eru niðurstöður í takt við erlendar rannsóknir, t.d. Biemiller og Boote (2006), Coyne og félaga (2007), Marulis og Neuman (2010) og Nash og Snowling (2006) um að börn læri betur ný orð með pví að fá pau útskýrð beint. Sömuleiðis hafa innlendar rannsóknir, par sem pátttakendur voru tvítyngd börn, sýnt hliðstæðar niðurstöður (Eyrún Rakel Agnarsdóttir, 2018; Helga Hilmarsdóttir, 2016).

Rannsóknir hafa einnig sýnt að pað að lesa fyrir börn hefur jákvæð áhrif á málproska peirra (Amalía Björnsdóttir o.fl., 2003; Hrafnhildur Ragnarsdóttir, 2015). Dó má draga pá ályktun að ekki sé sama hvernig lesið er fyrir börn, og pá sérstaklega börn með málproskaröskun. Börn með málproskaröskun purfa til dæmis að heyra ný orð oftar og yfir lengri tíma en börn með dæmigerðan málproska (Riches o.fl., 2005). Við athugun rannsakanda fyrir íhlutun, pegar fylgst var með börnunum í sögustund, kom í ljós að Tómas og Eva virtust ekki fylgjast með sem gefur til kynna að mögulega séu pau ekki að nýta sér sögulestur í hóp til að efla og auka málfærni sína, líkt og jafnaldrar með eðlilegan málproska gera alla jafna. Í pessari rannsókn kom í ljós að pau áttu erfitt með að geta sér til um merkingu orðanna út frá samhengi textans eða að nýta sér hliðstæð orð til að læra orð sem pau kunnu ekki fyrir. Hugsanlega voru bækurnar of pungar fyrir pau eða fyrst purfti að auka orðaforða peirra í fyrsta lagi orðaforðans (Beck o.fl., 2013). Dað er pví ljóst að pau purfa aðstoð við að læra ný orð og einnig við að skilja sögu pegar hún er lesin fyrir pau.

\section{Viðhelst pekking á nýjum orðum?}

Önnur rannsóknarspurningin sneri að pví hvort Tómas og Eva næðu að viðhalda pekkingu sinni á nýlærðum orðum mánuði eftir að íhlutun lyki. Niðurstöður sýndu að pekkingin viðhélst ekki að fullu hjá börnunum. Hjá Tómasi minnkaði pekking á markorðum um 13,9\% og á samanburðarorðum um 8,3\% frá íhlutunarskeiði. Hjá Evu varð líka lækkun í stigafjölda á orðaforðaprófinu, og meiri á markorðum en samanburðarorðum. Lækkunin á stigafjölda markorðanna hjá Evu nam um 16,6\% en um 2,8\% á samanburðarorðunum mánuði eftir að íhlutun lauk. Dessar niðurstöður eru ekki í samræmi við rannsókn Coyne og félaga (2007), en par viðhélst kunnátta barnanna á orðaforða sem kenndur var með beinni kennslu yfir átta vikna tímabil. Í meistaraprófsritgerð Helgu Hilmarsdóttur (2016), par sem hún prófaði sams konar aðferð á tvítyngdu barni, viðhélst pekkingin á markorðunum mánuði eftir að íhlutun lauk. Hins vegar eru pessar niðurstöður í samræmi við niðurstöður rannsókna um að börnum með málproskaröskun er hættara við að viðhalda ekki að fullu færni sem pau hafa náð með íhlutun (Riches o.fl., 2005). Tómas og Eva sýndu bæði meiri pekkingu á markorðum mánuði eftir að kennslu lauk en á prófunum fyrir íhlutun. Бað má pví draga pá ályktun að börn með málproskaröskun purfi viðhaldskennslu til að kunnátta peirra haldist. Hugsanlega væri nóg fyrir pau að heyra bækurnar lesnar aftur til að rifja upp orðin, pó svo að orðin væru ekki útskýrð sérstaklega. Pá heyrðu pau orðin reglulega, fengju endurtekningu og heyrðu pau í samhengi við texta.

\section{Málsýni}

Priðja rannsóknarspurningin fjallaði um hvort kennslan hefði áhrif á almenna máltjáningu í sjálfsprottnu tali eins og hún birtist í málsýnum. Peir mælikvarðar sem notaðir voru til að meta máltjáningu barnanna voru annars vegar fjöldi mismunandi orða og hins vegar hlutfallslegur fjöldi villna.

Samkvæmt greiningu á málsýnunum virtist orðaforðapjálfunin ekki hafa áhrif á almenna máltjáningu Tómasar og Evu í sjálfsprottnu tali. Рað er að segja, fjöldi mismunandi orða jókst ekki, sem segir að orðaforðinn varð ekki fjölbreyttari pegar pau tjáðu sig í sjálfsprottnu tali. Í flestum mælingum var FMO undir meðaltali jafnaldra (Jóhanna T. Einarsdóttir og Álfhildur Porsteinsdóttir, 2015). 
Hins vegar fækkaði villum í sjálfsprottnu tali eftir pví sem leið á pjálfunartímabilið pó að heildarfjöldi villna hafi í flestum mælingum verið mun meiri en hjá jafnöldrum (Jóhanna T. Einarsdóttir og Álfhildur Dorsteinsdóttir, 2015). Hlutfall fjölda villna var mest ́́ upphafi en lækkaði eftir að kennsla hófst og virtist ekki skipta máli hvort pjálfað var með beinni eða óbeinni kennslu. Af pessu má draga pá ályktun að allt pjálfunartímabilið, p.e. bæði pegar bein og óbein kennsla fór fram, hafi haft jákvæð áhrif pannig að villum fækkaði. Dó svo að markmiðið með pjálfuninni hafi ekki verið að fækka villum var rannsakandi sífellt að endurtaka á leiðréttandi hátt rangt tal (e. recasting). Degar börnin sögðu setningu eða orð sem voru málfræðilega röng endurtók rannsakandi setninguna eða orðið á leiðréttandi hátt. Bæði Tómas og Eva heyrðu pví stöðugt endurtekið pað sem pau sögðu með réttri málfræði. Auk pess fengu pau aukna athygli og gæðastund með einum fullorðnum einstaklingi með auknum samskiptum og samtali sem kann að hafa haft jákvæð áhrif á málfærni peirra.

\section{Takmarkanir rannsóknarinnar}

Rannsóknin var gerð að erlendri fyrirmynd en fjölmargar rannsóknir hafa sýnt fram á jákvæð áhrif beinnar kennslu með sögulestri (Beck o.fl., 2013; Biemeller og Boote, 2006; Coyne o.fl., 2007). Prófun úr markorðaforðanum parf að taka með fyrirvara. Mælitækið var hannað af rannsakanda að erlendri fyrirmynd. Баð var pví hvorki um neina staðla að ræða né reglur um fyrirgjöf eða forprófun. Рað var alltaf mat rannsakanda hvort pátttakendur fengu rétt eða rangt fyrir svarið. Раð hefði verið ákjósanlegt að nota staðlað orðaforðapróf samhliða sérhannaða mælitækinu. Mæling með sérhönnuðu orðaforðaprófi getur gefið ýkta mynd af orðaforðaaukningu par sem eingöngu er spurt um orðin sem verið er að vinna með. Ekki var lagt fyrir annað orðaforðapróf par sem ekki eru til íslenskir staðlar eða viðmið fyrir pess konar próf. Hins vegar voru tekin málsýni sem gáfu góða mynd af sjálfsprottnu tali barnanna. Par eru til íslensk viðmið sem eru afar gagnleg til að meta málproska barna í sjálfsprottnu tali samanborið við jafnaldra (Jóhanna T. Einarsdóttir og Álfhildur Dorsteinsdóttir, 2015).

Við val á pátttakendum má horfa til pess að Tómas er alinn upp við tvö tungumál pó svo íslenska sé hans sterkara mál og pað tungumál sem hann notar í samskiptum við aðra. Ákjósanlegast hefði verið að velja pátttakendur sem ólust eingöngu upp í íslensku málumhverfi, en par sem vitað var fyrirfram að Tómas var tæpum tveimur staðalfrávikum undir meðalgetu jafnaldra á íslensku og að hann talaði litla spænsku, pótti hann henta vel í pessa rannsókn. Tómas féll pví undir skilgreiningu málproskaröskunar par sem mikil frávik voru á báđum tungumálum í hans umhverfi.

Degar einliðasnið er notað, snið margpætts grunnskeiðs, skal ávallt hafa í huga áhrifapætti sem geta skekkt niðurstöður (Guðrún Árnadóttir og Dorlákur Karlsson, 2003). Î pessari rannsókn gæti pað t.d. hafa verið önnur kennsla samhliða rannsókninni. Par sem orðaforði er breyta sem erfitt er að hafa stjórn á var erfitt að útiloka ýmsa pætti sem gæetu haft áhrif. Dað var pó reynt eftir bestu getu, til dæmis með nákvæmum mælingum á meðferðarheldni íhlutunarinnar. Einnig með pví að fjarlægja pær bækur úr leikskólanum sem notaðar voru í kennslunni. Eins tóku pátttakendur ekki pátt í skipulögðum málörvunartímum í leikskólanum og tímum í talpjálfun var hætt á meðan rannsóknin fór fram. Samt sem áður var ekki hægt að hafa stjórn á öllum öđrum áhrifapáttum. Má par til dæmis nefna að Tómas og Eva fóru í samverustundir á hverjum degi par sem lesnar voru sögubækur. Ekki er hægt að útiloka að eitthvað af markorðunum 18 sem kennd voru og unnið með hafi komið fyrir í peim bókum.

\section{Ályktanir}

Í pessari rannsókn var orðaforðakennsla könnuð með lestri sögubóka hjá tveimur börnum með málproskaröskun. Niðurstöður benda til pess að orðaforðakennsla af pessu tagi, par sem orð eru útskýrð um leið og pau koma fyrir í sögubók, skili betri árangri en lestur sögubóka án pess að 
útskýra ákveðin orð. Dessar niðurstöður eru í samræmi við erlendar rannsóknir (t.d. Biemiller og Boote, 2006 og Coyne o.fl., 2007). Hins vegar hélst árangurinn ekki að fullu mánuði eftir að íhlutun lauk. Рað bendir til pess að börn með málproskaröskun purfi stöðuga örvun til að viðhalda orðaforða sínum. Detta er mikilvægt að hafa í huga pegar verið er að leiðbeina foreldrum og leikskólakennurum barna sem eru með frávik í máli. Pau purfa aðstoð við að skilja sögurnar, pau purfa beina útskýringu á orðum og pað verður að gæta pess að málfar bókanna sé við hæfi. Orðaforðakennsla af pessu tagi er mikilvæg fyrir börn með málproskafrávik en pað er ljóst að börnin purfa meiri og markvissari örvun bæði starfsmanna leikskólans og foreldra til að málörvunin yfirfærist á sjálfsprottið tal.

\section{Vocabulary intervention through storybook reading for children with developmental language disorder}

Children diagnosed with developmental language disorders (DLD) have difficulty learning language. This affects both language comprehension and expression and occurs without any obvious explanation. Many children with DLD have coexisting conditions, such as attentional or emotional problems. Children with DLD can have different types of difficulties learning language and the severity varies. The symptoms are numerous, including problems with learning and applying the rules of grammar, sentence construction, and language use. One common symptom is limited vocabulary. Children with DLD have smaller receptive and expressive vocabularies than their peers. They learn new words at slower rate and forget newly acquired words more rapidly. They know fewer words and have weaker semantic connections within their lexical system. This deficit is visible in their expressive language as they often use simple, high frequency vocabulary. This lack of vocabulary diversity can affect their future reading comprehension and academic performance. Research have shown that DLD is common, with approximately $9 \%$ of children displaying signs of language impairment without other coexisting difficulties. Considered in the context of the population of Iceland, this means that approximately 400 children in every year-based age group could be affected by DLD.

The aim of this project was to examine the effect of an intervention which aimed to increase the vocabulary of two children diagnosed with DLD. Both attended the same preschool and were in their last year in the preschool where the training took place. The training involved reading a story book where two different methods of teaching target words were compared. The words were either (a) explained explicitly and directly when they occurred in the text, or (b) indirectly when the children were exposed to the words in the text but without explicit teaching. A multiple baseline design was employed by comparing the intervention methods between the children. The intervention took place four times a week for six weeks. Child A received indirect teaching in the first week, then two weeks of direct teaching, followed by three weeks of indirect teaching. As regards Child B, indirect teaching occurred in the first four weeks, followed by direct teaching during the last two weeks. The effect of the intervention was measured by testing how well the children could define the target words and by language samples of spontaneous speech. Measurements were made before, during, and immediately following training, as well as a month after training ended.

Expanding vocabulary by direct teaching was found to be a more powerful method than indirect teaching. Vocabulary training using direct teaching had a positive effect with regard to the words taught. Measurements showed that when direct teaching was conducted the children in this study knew the words and were able to explain 
them, whereas their vocabulary improved only slightly when indirect teaching methods were applied. Measurements taken a month after intervention showed that the children did not fully retain the newly gained vocabulary. It is clear, however, that to maintain the newly gained vocabulary repeated reading, including discussion of target words, is necessary for children with DLD. Reading storybooks with or without direct teaching of target words did not affect the children's spontaneous vocabulary use as measured by language samples; that is, they did not begin to use more complex and different words when speaking spontaneously. However, on average the children produced more grammatically correct sentences and made fewer morphemic errors.

The findings of this study show the importance of reading story books to children during their preschool years. The findings demonstrate that for learning new words children with poor language skills need direct teaching and repeated intensive instruction. It is not enough merely to read the stories without explaining unknown new words. Furthermore, repeated measurements showed that during and after the intervention the children spoke with fewer grammatical errors. This is probably because the researcher made intensive use of the method of recasting during the intervention. Recasting has been shown to be an effective way of correcting syntactic and grammatical errors.

The study also demonstrated the importance of supporting children with poor language skills and facilitating their language acquisition. These results can be used for the benefit of parents, teachers and speech pathologists alike.

Key words: Language development, developmental language disorder, story book reading, explicit and implicit vocabulary intervention

\section{Um höfundana}

Sigrún Alda Sigfúsdóttir (sigrunalda88@gmail.com) er talmeinafræðingur og starfar á Talsetrinu og hjá Reykjavíkurborg. Sigrún Alda lauk MS-prófi í talmeinafræði frá Háskóla Íslands árið 2018 og BA-prófi í félagsráđgjöf frá Háskóla Íslands árið 2012.

Jóhanna T. Einarsdóttir (jeinars@hi.is) er talmeinafræðingur og dósent við Háskóla Íslands á Mennta- og Heilbrigðisvísindasviði. Hún lauk doktorsprófi frá Læknadeild Háskóla Íslands árið 2009. Rannsóknir Jóhönnu Thelmu hafa beinst að máltöku barna á leikskólaaldri, bæði mælingum á málproska og íhlutun. Hún hefur einnig rannsakað stam, greiningu pess og meðferð hjá öllum aldurshópum.

Porlákur Karlsson (thorlakur@ru.is) er sálfræðingur og dósent í sálfræði við Háskólann í Reykjavík. Hann er með doktorspróf í sálfræði frá West Virginia University (1990) með atferlisgreiningu sem aðalgrein en tölfræði og aðferðafræði sem aukagrein. Rannsóknir hans eru helst á sviði aðferðafræði rannsókna og launamunar kynja.

Íris Ösp Bergbórsdóttir (iob@hi.is) stundar doktorsnám við Heilbrigðisvísindasvið Háskóla Íslands, rannsókn hennar snýr að meðferðarheldni í foreldramiðaðri stamrannsókn á börnum. Hún lauk MS-prófi í Viðskiptafræði frá Háskóla Íslands árið 2006 og BS-prófi í sálfræði frá Háskóla Íslands árið 2001. Rannsóknir hennar eru helst á sviði meðferðarheldnis og frammistöðumatsmælinga. 


\section{About the authors}

Sigrún Alda Sigfúsdóttir (sigrunalda88@gmail.com ) is a speech-language pathologist working for Talsetrið and The City of Reykjavík. Sigrún Alda completed an M.S. degree in speech-language pathology from the medical department at the University of Iceland in 2018 and a bachelor's degree in Social studies from the University of Iceland in 2012.

Jóhanna T. Einarsdóttir (jeinars@hi.is) is an associate professor at the University of Iceland School of Education and School of Health Sciences. She received her PhD in 2009 from the medical department at the University of Iceland. Jóhanna has been investigating children's language acquisition in early childhood, measurements as well as intervention. Her special interests are fluency disorders, stuttering and stuttering treatment.

Thorlakur Karlsson (thorlakur@ru.is) is a psychologist and an associate professor at Reykjavík University. He has a doctoral degree in psychology from West Virginia University (1990), with a major in behavior analysis and a minor in statistics and methodology. His research is mainly in the area of methodology and gender wage difference.

Íris Ösp Bergpórsdóttir (iob@hi.is) is a PhD student within the School of Health Science at the University of Iceland. Her doctoral research investigates implementation fidelity in parent-managed treatments for children. Íris completed her M.S. degree in business from the University of Iceland in 2006 and a bachelor's degree in psychology from the University of Iceland in 2001. Her research is mainly in the area of fidelity and performance research.

\section{Heimildir}

Amalía Björnsdóttir, Ingibjörg Símonardóttir og Jóhanna Einarsdóttir. (2003). Próun HLJÓM-2 og tengsl pess við lestrarfærni og ýmsa félagslega pætti. Uppeldi og menntun, 12, 9-30.

Árdís Hrönn Jónsdóttir. (2013). Orðaspjall: Að efla orðaforða og hlustunarskilning barna með bókalestri. Reykjanesbær: Leikskólinn Tjarnarsel.

Beach, K. D., Sanchez,V., Flynn, L. J. og O’Connor, R. (2015). Teaching academic vocabulary to adolescents with learning disabilities. Teaching Exceptional Children, 48(1), 36-44. doi:10.1177/0040059915594783

Beck, I. L. og McKeown, M. G. (2007). Increasing young low-income children's oral vocabulary repertoires through rich and focused instruction. Elementary School Journal, 107(3), 251-271. doi:10.1086/511706

Beck, I. L., McKeown, M. G. og Kucan, L. (2013). Bringing words to life: Robust vocabulary instruction. New York, NY: Guilford Press.

Beck, I. L., Perfetti, C.A. og McKeown, M. G. (1982). Effects of long-term vocabulary instruction on lexical access and reading comprehension. Journal of Educational Psychology, 74(4), 506-521. doi:10.1037/00220663.74.4.506

Biemiller, A. og Boote, C. (2006). An effective method for building meaning vocabulary in primary grades. Journal of Educational Psychology, 98(1), 44-62. doi:10.1037/0022-0663.98.1.44

Bishop, D.V. M., Snowling, M. J., Thompson, P. A. og Greenhalgh, T. (2016). CATALISE: A multinational and multidisciplinary Delphi consensus study. Identifying language impairments in children. PLoS ONE 11(7), 1-26. doi:10.1371/journal.pone.0158753

Bishop, D.V. M., Snowling, M.J., Thompson, P.A. og Greenhalgh,T. (2017). Phase 2 of CATALISE:A multinational and multidisciplinary Delphi consensus study of problems with language development:Terminology. Journal of Child Psychology and Psychiatry, 58(10), 1068-1080. doi:10.1111/jcpp.12721 
Catts, H.W., Fey, M. E., Tomblin, J. B. og Zhang, X. (2002). A longitudinal investigation of reading outcomes in children with language impairments. Journal of Speech, Language, and Hearing Research, 45(6), 1142-1157. doi:10.1044/1092-4388(2002/093)

Coyne, M. D., McCoach, D. B. og Kapp, S. (2007).Vocabulary intervention for kindergarten students: Comparing extended instruction to embedded instruction and incidental exposure. Learning Disability Quarterly, 30(2), 74-88. doi:10.2307/30035543

Dusenbury, L., Brannigan, R., Falco, M. og Hansen, W. B. (2003). A review of research on fidelity of implementation: Implications for drug abuse prevention in school settings. Health Education Research, 18(2), 237-256. doi:10.1093/her/18.2.237

Eyrún Rakel Agnarsdóttir. (2018). Djálfun orđaforða tvítyngdra barna með lestri sögubóka. Bein og óbein pjálfun (óútgefin meistararitgerð). Heilbrigðisvísindasvið, Háskóli Íslands, Reykjavík.

Guðrún Árnadóttir og Porlákur Karlsson. (2003). Einliðasnið: Öflug leið til samhæfingar klínískrar vinnu og rannsókna. Í Sigríður Halldórsdóttir og Kristján Kristjánsson (ritstjórar), Handbók i a đferðafraðði og rannsóknum í heilbrigðisvísindum (bls. 295-330). Akureyri: Háskólinn á Akureyri.

Helga Hilmarsdóttir. (2016). Orðaforði tvítyngdra barna - Orðaforðabjálfun með lestri sögubóka (óútgefin meistararitgerð). Heilbrigðisvísindasvið, Háskóli Íslands, Reykjavík.

Hiebert, E. H. og Kamil, M. L. (2005). Teaching and learning vocabulary: Bringing research to practice. London, UK: Routledge. doi:10.4324/978141061

Hrafnhildur Ragnarsdóttir. (2015). Málproski leikskólabarna. Próun orðaforða, málfræði og hlustunarskilnings milli fjögra og fimm ára aldurs. Netla - Veftímarit um uppeldi og menntun. Sótt af http://netla.hi.is/ greinar/2015/ryn/007.pdf

Jóhanna T. Einarsdóttir, Amalía Björnsdóttir og Ingibjörg Símonardóttir. (2016). The predictive value of preschool language assessments on academic achievement: A 10-year longitudinal study of Icelandic children. American Journal of Speech-Language Pathology, 25(1), 67-79. doi:10.1044/2015_AJSLP-14-0184

Jóhanna T. Einarsdóttir og Álfhildur Porsteinsdóttir. (2015). Málsýni leikskólabarna: Aldursbundin viðmið. Netla - Veftímarit um uppeldi og menntun. Sótt af http://netla.hi.is/greinar/2015/ryn/010.pdf

Jóhanna Thelma Einarsdóttir og Stefán Carl Peiser. (2016). Málgreinir. Sótt af http://malsyni.hi.is/?page_id=184

Jóhanna Thelma Einarsdóttir og Dóra Sæunn Úlfsdóttir. (2018). Málsýnataka. Sótt af http://malsyni.hi.is/ wp-content/uploads/2018/02/handb\%C3\%B3k-6.2.2018.pdf

Kazdin, A. E. (2011). Single-case research designs: Methods for clinical and applied settings (2. útgáfa). Oxford, UK: Oxford University Press.

Laufer, B. og Ravenhorst-Kalovski, G. C. (2010). Lexical threshold revisited: Lexical text coverage, learners' vocabulary size and reading comprehension. Reading in a Foreign Language, 22(1), 15-30.

Law, J. (2019). Introduction. Í J. Law, C. McKean, C. A. Murphy og E. Thordardottir (ritstjórar), Managing children with developmental language disorders. Theory and practice across Europe and beyond (bls. 3-5). London, UK: Routledge.

Liebermann-Betz, R. G. (2015). A systematic review of fidelity of implementation in parent-mediated early communication intervention. Topics in Early Childhood Special Education, 35(1), 15-27. doi:10.1177/0271121414557282

Marulis, L. M. og Neuman, S. B. (2010). The effects of vocabulary intervention on young children's word learning: A meta-analysis. Review of Educational Research, 80(3), 300-334. doi:10.3102/0034654310377087

McGregor, K. K., Oleson, J., Bahnsen, A. og Duff, D. (2013). Children with developmental language impairment have vocabulary deficits characterized by limited breadth and depth. International Journal of Language and Communication Disorders, 43(3), 307-319. doi:10.1111/1460-6984.12008

McKeown, M. G. og Beck, L. (2014). Effects of vocabulary instruction on measures of language processing: Comparing two approaches. Early Childhood Research Quarterly, 29(4), 520-530. doi:10.1016/j.ecresq.2014.06.002

McKeown, M. G., Beck, I. L., Omanson, R. C. og Perfetti, C.A. (1983). The effects of long-term vocabulary instruction on reading comprehension: A replication. Journal of Reading Behavior, 15(1),3-18. doi:10.1080/10862968309547474 
McKeown, M. G., Beck, I. L., Omanson, R. C. og Pople, M. T. (1985). Some effects of the nature and frequency of vocabulary instruction on the knowledge and use of words. Reading Research Quarterly, 20(5), 522-535. doi:10.2307/747940

Nash, H. og Snowling, M. (2006). Teaching new words to children with poor existing vocabulary knowledge: A controlled evaluation of the definition and context methods. International Journal of Language $\mathcal{E}$ Communication Disorders, 41(3), 335-354. doi:10.1080/13682820600602295

Nation, K. og Snowling, M.J. (2004). Beyond phonological skills: Broader language skills contribute to the development of reading. Journal of Research in Reading, 27(4), 342-356. doi:10.1111/j.1467-9817.2004.00238.x

National Institute of Child Health and Human Development. (2000). Report of the National Reading Panel. Teaching children to read: An evidence based assessment of the scientific research literature on reading and its implications for reading instruction. Washington, DC: Government Printing Office.

Paul, R., Norbury, C. og Gosse, C. (2018). Language disorders from infancy through adolescence: Assessment and intervention (5. útgáfa). St. Louis, MA: Mosby Elsevier.

RADLD. (e.d.). Raising awareness of developmental language disorder. Sótt af https://radld.org/

Rice, M. L., Buhr, J. C. og Nemeth, M. (1990). Fast mapping word-learning abilities of language-delayed preschoolers. Journal of Speech and Hearing Disorders, 55(1), 33-42. doi:10.1044/jshd.5501.33

Riches, N. G., Tomasello, M. og Conti-Ramsden, G. (2005).Verb learning in children with SLI: Frequency and spacing effects. Journal of Speech, Language and Hearing Research, 48(6), 1397-1411. doi:10.1044/10924388(2005/097)

Walsh, B. A. og Blewitt, P. (2006). The effect of questioning style during storybook reading on novel vocabulary acquisition of preschoolers. Early Childhood Education Journal, 33(4), 273-278. doi:10.1007/ s10643-005-0052-0

Wasik, B. A. og Bond, M. A. (2001). Beyond the pages of a book: Interactive book reading and language development in preschool classrooms. Journal of Educational Psychology, 93(2), 243-250. doi:10.1037/00220663.93.2.243

Wilkinson, K. S. og Houston-Price, C. (2013). Once upon a time, there was a pulchritudinous princess... : The role of word definitions and multiple story contexts in children's learning of difficult vocabulary. Applied Psycholinguistics, 34(3), 591-613. doi:10.1017/S0142716411000889

Sigrún Alda Sigfúsdóttir, Jóhanna T. Einarsdóttir, Dorlákur Karlsson og Íris Ösp Bergbórsdóttir. (2020).

Orðaforðakennsla með sögulestri fyrir börn með málproskaröskun

Netla - Veftímarit um uppeldi og menntun. Menntavísindasvið Háskóla Íslands.

Sótt af http://netla.hi.is/greinar/2020/ryn/04

DOI: https://doi.org/10.24270/netla.2020.4 
